\title{
Risk factors for proliferative sickle retinopathy
}

\author{
Peter D Fox, David T Dunn, Joanne S Morris, Graham R Serjeant
}

\begin{abstract}
The prevalence, incidence, and risk factors associated with proliferative sickle retinopathy (PSR) were investigated in 786 patients with homozygous sickle cell (SS) disease and 533 patients with sickle cell haemoglobin $\mathrm{C}$ (SC) disease. PSR was more common in SC disease, in which there was a significant predominance of males, and it increased with age in both genotypes. In SC disease the risk of developing PSR was highest between 15 and 24 years in males, between 20 and 39 years in females, and in SS disease between 25 and 39 years in both sexes. PSR tended to be bilateral, especially in SC disease. There was no evidence of familial clustering of PSR in SC siblings, and insufficient numbers of SS siblings were available to test for clustering. Haematological risk factors associated with PSR in SS disease were a high haemoglobin in males and a low fetal haemoglobin in both sexes and in SC disease, a high mean cell volume, and a low fetal haemoglobin in females.
\end{abstract}

Proliferative sickle retinopathy (PSR) is the major sight threatening complication in sickle cell eye disease, and may reach frequencies as high as $70 \%$ in patients with sickle cell haemoglobin C (SC) disease. The risk factors for its development are still largely unknown, partly because detailed ocular information has not been available in sickle cell populations large enough to allow comprehensive statistical analysis. A study of 261 patients with homozygous sickle cell (SS) disease including 29 with PSR noted that male patients with PSR had significantly higher total haemoglobin $(\mathrm{Hb})$ and lower fetal haemoglobin (HbF) but that no correlations occurred in females. ' Another study of 243 patients with SC disease including 90 with PSR found significant correlations of PSR with low HbF in both sexes and with a high mean cell volume (MCV) in males. ${ }^{2}$ Since those earlier Jamaican reports 333 cases of PSR including 112 incident cases have been observed. This larger group has enabled more detailed analyses on prevalence, incidence, familial clustering, and haematological risk factors. The results of these analyses are now presented.

\footnotetext{
Medical Research

Council Laboratories

(Jamaica), University of the West Indies, Kingston, Jamaica P D Fox D T Dunn I S Morris G S Morris Correspondence to: $\operatorname{Dr} \mathbf{G} R$ Serjeant, Medical Research Council Laboratories (Jamaica), University of the West Indies, Kingston 7, Jamaica, WI.

Accepted for publication 12 September 1989
} The patients attended the Sickle Cell Clini the University of the West Indies. All SS and SC patients examined between August 1970 and October 1988 were included in this study, though children in a cohort study from birth were excluded. Ocular examination included visual acuities, fundal examination through dilated pupils, and fluorescein angiography where indicated. Patients were classified as having PSR regardless of whether or not the lesions were perfused when examined.

The patient's age and PSR status for the prevalence analysis was defined at the first eye examination. As patients with proliferative disease were reviewed more frequently, using age at last visit would have exaggerated the prevalence of PSR. Therefore all cases of PSR that developed during the study were excluded from the prevalence analysis. The exact age at onset of PSR was rarely available, and for the incidence analysis it was assumed that PSR developed at the mid point between the last negative and the first positive examination. Patients were divided into the following age groups for analysis: 0-9 years, 10-14, 15-19, 20 $24,25-29,30-39$, and 40 years and above.

The diagnosis of SS and SC disease was based on standard criteria. ${ }^{4}$ Haemoglobin, red cell indices, and platelets were measured in electronic counters (Coulter ZBI6 or $S$ plus 4, Coulter Electronics), fetal haemoglobin (HbF) by an alkali denaturation method, ${ }^{5}$ bilirubin by the method of Lathe and Ruthven, ${ }^{6}$ and serum iron by the method of Beale et al. ${ }^{7}$ Mean cell haemoglobin concentration (MCHC) was derived from the spun microhaematocrit. $\alpha$ Thalassaemia status was determined by restriction endonuclease analysis of DNA obtained from the buffy coat. ${ }^{8}$

For comparison of haematological indices in patients with and without PSR at their last examination, levels were derived from the mean of multiple steady state observations. This study was confined to a subset of 1181 patients $(740 \mathrm{SS}$, 441 SC) for whom complete haematological data were available. Indices with skewed distributions ( $\mathrm{HbF}$, bilirubin) were logarithmically transformed ( $\log _{10}[\mathrm{HbF}+1], \log _{10}$ bilirubin) to give more normal distributions prior to statistical analysis. Simple comparison of the distribution of haematological indices between patients with and without PSR can be misleading, as certain indices are interdependent and age related, so multiple logistic regression analysis ${ }^{9}$ was also used, separately for both sexes and genotypes. This approach assessed the effect of a factor assuming all other factors in the model were fixed and allowed for age related trends. Haematological indices that appeared to influence the simple comparison by Student's $t$ test were included in the logistic regression. Comparison of proportions across age groups was performed by the Mantel-Haenszel test, and a log linear regression model was used to analyse age related trends in incidence.

\section{Results}

A total of 786 SS and 533 SC patients were examined, representing $29 \%$ of all SS patients and $55 \%$ of all SC patients registered at the clinic. 
TABLE I Prevalence of proliferative sickle retinopathy at first examination by sex and age in 786 SS patients

\begin{tabular}{|c|c|c|c|c|c|c|c|c|c|}
\hline \multirow{3}{*}{$\begin{array}{l}\text { Age group } \\
\text { (years) }\end{array}$} & \multicolumn{3}{|l|}{ Males } & \multicolumn{3}{|l|}{ Females } & \multicolumn{3}{|l|}{ Both sexes } \\
\hline & \multirow{2}{*}{$\begin{array}{l}\text { Patients } \\
\text { examined }\end{array}$} & \multicolumn{2}{|c|}{ Pts with PSR } & \multirow{2}{*}{$\begin{array}{l}\text { Patients } \\
\text { examined }\end{array}$} & \multicolumn{2}{|c|}{ Pts with PSR } & \multirow{2}{*}{$\begin{array}{l}\text { Patients } \\
\text { examined }\end{array}$} & \multicolumn{2}{|c|}{ Pts with PSR } \\
\hline & & No. & $(\%)$ & & No. & $(\%)$ & & No. & $(\%)$ \\
\hline $\begin{array}{l}0-9 \\
10-14 \\
15-19 \\
20-24 \\
25-29 \\
30-39 \\
40 \text { plus } \\
\text { Total }\end{array}$ & $\begin{array}{r}8 \\
38 \\
68 \\
72 \\
46 \\
55 \\
41 \\
328\end{array}$ & $\begin{array}{r}0 \\
0 \\
2 \\
3 \\
2 \\
14 \\
4 \\
25\end{array}$ & $\begin{array}{c}(0) \\
(0) \\
(3) \\
(4) \\
(4) \\
(25) \\
(10) \\
(8 \%)\end{array}$ & $\begin{array}{r}9 \\
42 \\
99 \\
98 \\
61 \\
79 \\
70 \\
458\end{array}$ & $\begin{array}{r}0 \\
0 \\
1 \\
2 \\
4 \\
9 \\
8 \\
24\end{array}$ & $\begin{array}{c}(0) \\
(0) \\
(1) \\
(2) \\
(7) \\
(11) \\
(11) \\
(5 \%)\end{array}$ & $\begin{array}{r}17 \\
80 \\
167 \\
170 \\
107 \\
134 \\
111 \\
786\end{array}$ & $\begin{array}{r}0 \\
0 \\
3 \\
5 \\
6 \\
23 \\
12 \\
49\end{array}$ & $\begin{array}{l}(0) \\
(0) \\
(2) \\
(3) \\
(6) \\
(17) \\
(11) \\
(6 \%)\end{array}$ \\
\hline
\end{tabular}

TABLE II Prevalence of proliferative sickle retinopathy at first examination by sex and age in 533 SC patients

\begin{tabular}{|c|c|c|c|c|c|c|c|c|c|}
\hline \multirow{3}{*}{$\begin{array}{l}\text { Age group } \\
\text { (years) }\end{array}$} & \multicolumn{3}{|l|}{ Males } & \multicolumn{3}{|l|}{ Females } & \multicolumn{3}{|l|}{ Both sexes } \\
\hline & \multirow{2}{*}{$\begin{array}{l}\text { Patients } \\
\text { examined }\end{array}$} & \multicolumn{2}{|c|}{ Pts with PSR } & \multirow{2}{*}{$\begin{array}{l}\text { Patients } \\
\text { examined }\end{array}$} & \multicolumn{2}{|c|}{ Pts with PSR } & \multirow{2}{*}{$\begin{array}{l}\text { Patients } \\
\text { examined }\end{array}$} & \multicolumn{2}{|c|}{ Pts with PSR } \\
\hline & & No. & $(\%)$ & & No. & $(\%)$ & & No. & $(\%)$ \\
\hline $\begin{array}{c}0-9 \\
10-14 \\
15-19 \\
20-24 \\
25-29 \\
30-39 \\
40 \text { plus } \\
\text { Total }\end{array}$ & $\begin{array}{r}26 \\
36 \\
49 \\
33 \\
32 \\
44 \\
26 \\
246\end{array}$ & $\begin{array}{r}0 \\
2 \\
9 \\
14 \\
25 \\
30 \\
18 \\
98\end{array}$ & $\begin{array}{l}(0) \\
(6) \\
(18) \\
(42) \\
(78) \\
(68) \\
(69) \\
(40 \%)\end{array}$ & $\begin{array}{r}21 \\
41 \\
68 \\
48 \\
35 \\
44 \\
30 \\
287\end{array}$ & $\begin{array}{r}0 \\
3 \\
7 \\
8 \\
15 \\
20 \\
21 \\
74\end{array}$ & $\begin{array}{l}(0) \\
(7) \\
(10) \\
(17) \\
(43) \\
(45) \\
(70) \\
(30 \%)\end{array}$ & $\begin{array}{r}47 \\
77 \\
117 \\
81 \\
67 \\
88 \\
56 \\
533\end{array}$ & $\begin{array}{r}0 \\
5 \\
16 \\
22 \\
40 \\
50 \\
39 \\
172\end{array}$ & $\begin{array}{l}(0) \\
(6) \\
(14) \\
(27) \\
(60) \\
(57) \\
(70) \\
(32 \%)\end{array}$ \\
\hline
\end{tabular}

TABLE III Incidence rates for first development of proliferative sickle retinopathy in $41 \mathrm{SS}$ patients

\begin{tabular}{|c|c|c|c|c|c|c|c|}
\hline \multirow[b]{2}{*}{$\begin{array}{l}\text { Age group } \\
\text { (years) }\end{array}$} & \multicolumn{3}{|l|}{ Males } & \multicolumn{3}{|c|}{ Females } & \multirow{2}{*}{$\begin{array}{l}\text { Both sexes } \\
\text { Incidence } \\
\text { (per 100 } \\
\text { pt.-years) }\end{array}$} \\
\hline & $\begin{array}{l}\text { New } \\
P S R\end{array}$ & $\begin{array}{l}\text { Pt.-years } \\
\text { observation }\end{array}$ & $\begin{array}{l}\text { Incidence } \\
\text { (per 100 } \\
\text { pt.-years) }\end{array}$ & $\begin{array}{l}\text { New } \\
\text { PSR }\end{array}$ & $\begin{array}{l}\text { Pt.-years } \\
\text { observation }\end{array}$ & $\begin{array}{l}\text { Incidence } \\
\text { (per 100 } \\
\text { pt.-years) }\end{array}$ & \\
\hline $0-9$ & 0 & 2 & 0.0 & 0 & 1 & 0.0 & 0.0 \\
\hline $10-14$ & 0 & 31 & 0.0 & 0 & 63 & 0.0 & 0.0 \\
\hline $15-19$ & 2 & 110 & 1.8 & 2 & 157 & $1 \cdot 3$ & 1.5 \\
\hline $20-24$ & 2 & 131 & 1.5 & 2 & 167 & $1 \cdot 2$ & $1 \cdot 3$ \\
\hline $25-29$ & 3 & 124 & $2 \cdot 4$ & 4 & 160 & 2.5 & $2 \cdot 5$ \\
\hline $30-39$ & 4 & 150 & $2 \cdot 7$ & 6 & 219 & $2 \cdot 7$ & $2 \cdot 7$ \\
\hline 40 plus & 5 & 256 & $2 \cdot 0$ & 11 & 378 & $2 \cdot 9$ & 2.5 \\
\hline Total & 16 & 804 & $2 \cdot 0$ & 25 & 1145 & $2 \cdot 2$ & $2 \cdot 1$ \\
\hline
\end{tabular}

TABLE IV Incidence rates for first development of proliferative sickle retinopathy in 71 SC patients

\begin{tabular}{|c|c|c|c|c|c|c|c|}
\hline \multirow[b]{2}{*}{$\begin{array}{l}\text { Age group } \\
\text { (years) }\end{array}$} & \multicolumn{3}{|c|}{ Males } & \multicolumn{3}{|c|}{ Females } & \multirow{2}{*}{$\begin{array}{l}\text { Both sexes } \\
\text { Incidence } \\
\text { (per } 100 \\
\text { pt.-years) }\end{array}$} \\
\hline & $\begin{array}{l}\text { New } \\
P S R\end{array}$ & $\begin{array}{l}\text { Pt.-years } \\
\text { observation }\end{array}$ & $\begin{array}{l}\text { Incidence } \\
\text { (per 100 } \\
\text { pt.-years) }\end{array}$ & $\begin{array}{l}\text { New } \\
\text { PSR }\end{array}$ & $\begin{array}{l}\text { Pt.-years } \\
\text { observation }\end{array}$ & $\begin{array}{l}\text { Incidence } \\
\text { (per 100 } \\
\text { pt.-years) }\end{array}$ & \\
\hline $\begin{array}{l}0-9 \\
10-14 \\
15-19 \\
20-24 \\
25-29 \\
30-39 \\
40 \text { plus } \\
\text { Total }\end{array}$ & $\begin{array}{r}0 \\
2 \\
12 \\
10 \\
1 \\
2 \\
2 \\
29\end{array}$ & $\begin{array}{r}56 \\
118 \\
176 \\
115 \\
21 \\
40 \\
43 \\
569\end{array}$ & $\begin{array}{l}0 \cdot 0 \\
1 \cdot 7 \\
6 \cdot 8 \\
8 \cdot 7 \\
4 \cdot 8 \\
5 \cdot 0 \\
4 \cdot 6 \\
5 \cdot 1\end{array}$ & $\begin{array}{r}0 \\
7 \\
5 \\
11 \\
8 \\
9 \\
2 \\
42\end{array}$ & $\begin{array}{r}37 \\
121 \\
181 \\
152 \\
83 \\
108 \\
70 \\
752\end{array}$ & $\begin{array}{l}0 \cdot 0 \\
5 \cdot 8 \\
2 \cdot 8 \\
7 \cdot 2 \\
9 \cdot 6 \\
8 \cdot 3 \\
2 \cdot 9 \\
5 \cdot 6\end{array}$ & $\begin{array}{l}0 \cdot 0 \\
3 \cdot 8 \\
4 \cdot 8 \\
7 \cdot 9 \\
8 \cdot 6 \\
7 \cdot 4 \\
3 \cdot 5 \\
5 \cdot 4\end{array}$ \\
\hline
\end{tabular}

The excess of females examined $(58 \%$ SS, $54 \%$ SC) reflects the attendance pattern of the clinic. Proportionately more of the SC patients were examined because of the known higher prevalence of PSR in SC disease and because they comprised a greater proportion of the adult clinic.

PREVALENCE

The prevalence of PSR at the initial eye examination by age group in SS and SC disease is shown in Tables I and II respectively. Proliferative retinopathy was more common in SC than SS disease $(p<0.001)$ and increased with age in both genotypes. In SS disease PSR was first observed in the 15-19 years age group, and the prevalence increased gradually to peak in patients aged 30 years and over. The apparent fall in frequency of PSR in male SS patients from the 30-39 year age group to the 40 years and over age group was not significant. In SC disease PSR was first seen in the 10-14-year age group, and the prevalence of PSR increased steeply with age, reaching maximum frequencies in SC males in the 25-29-year age group and in $\mathrm{SC}$ females aged 40 and above. As to the effect of sex, males with SC disease were significantly more likely to have PSR than females $(p<0.001)$, but a similar trend in SS disease was not significant $(p=0 \cdot 14)$. Symptoms attributable to PSR prior to first eye examination occurred in $10 \%$ SC patients and $1 \%$ SS patients, but symptomatic referral did not significantly affect the prevalence data.

\section{INCIDENCE}

The development of PSR for the first time was observed in 41 patients with SS disease (Table III) and in 71 patients with SC disease (Table IV). In SS disease incident cases were first observed in the 15-19 year age group, and the incidence rate appeared to increase to those aged 25 and over, though this trend was not significant. In SC disease incident cases first occurred in the 10-14 year age group, and incidence rates peaked at age 20-24 in males and at age 25-29 in females. However, neither the age related trend nor the apparent sex difference in SC disease reached statistical significance.

\section{BILATERAL ITY}

The frequency of bilateral involvement was examined, since this may distinguish the role of systemic factors (favouring bilateral involvement) from local factors (favouring unilateral involvement). Bilateral PSR occurred in 44/90 (49\%) of patients with SS disease and in 170/243 (70\%) of patients with SC disease, being significantly more common $(p<0.001)$ in SC disease. In both genotypes bilateral PSR was more common than would be expected if PSR had developed independently in the second eye $(p<0.001)$.

The development of bilateral PSR was prospectively observed in the study in 59 patients (18 SS, 41 SC). The interval between onset in the first and second eye was examined, since simultaneous onset might reflect some acute haematological change or clinical event relevant to the pathogenesis of PSR. In only three patients (1 SS, 2 SC) was PSR observed to develop in both eyes within one year, and in none did this occur simultaneously. In 14 patients (2 SS, 12 SC) the interval between onset in the first and second eyes was at least one year. In the remaining 42 patients the intervals between visits were too irregular to provide useful data.

FAMILIAL CLUSTERING

The clustering of PSR affected patients within families was examined, since this might identify other genetic factors relevant to the development of PSR. In SS disease there were insufficient numbers of PSR affected patients to conduct this 
TABLE V Familial clustering of proliferative sickle retinopathy within families with SC disease

\begin{tabular}{|c|c|c|c|c|c|c|}
\hline \multirow[b]{3}{*}{$\begin{array}{l}\text { Sibling } \\
\text { with } P S R\end{array}$} & \multicolumn{6}{|c|}{ Number of siblings examined } \\
\hline & \multicolumn{3}{|l|}{2} & \multicolumn{3}{|l|}{3} \\
\hline & $\begin{array}{l}\text { Observed } \\
(O)\end{array}$ & $\begin{array}{l}\text { Expected } \\
(E)\end{array}$ & $O-E$ & $\begin{array}{l}\text { Observed } \\
(O)\end{array}$ & $\begin{array}{l}\text { Expected } \\
(E)\end{array}$ & $O-E$ \\
\hline $\begin{array}{l}0 \\
1 \\
2 \\
3\end{array}$ & $\begin{array}{l}11 \\
13 \\
10 \\
-\end{array}$ & $\begin{array}{r}10 \cdot 1 \\
15 \cdot 1 \\
8 \cdot 8 \\
-\end{array}$ & $\begin{array}{r}0.9 \\
-2.1 \\
1.2 \\
-\end{array}$ & $\begin{array}{l}3 \\
4 \\
2 \\
3\end{array}$ & $\begin{array}{l}2.3 \\
4.5 \\
3.7 \\
1.5\end{array}$ & $\begin{array}{r}0.7 \\
-0.5 \\
-1.7 \\
1.5\end{array}$ \\
\hline
\end{tabular}

analysis. In SC disease there were 62 families with two or more affected siblings for whom the results of eye examinations were available (34 sets of two siblings, 12 sets of three siblings, and one set of six siblings). From age/sex specific prevalence data the probability of observing 0,1 , 2, or 3 siblings with PSR within each family was calculated. Summing these probabilities over families gave the expected numbers of families with $0,1,2$, or 3 cases of PSR. Familial clustering would be indicated by an excess of families in which none or all of the siblings had PSR, which was not supported by the data (Table V). In the family of six siblings five had PSR, but this was not an improbable occurrence (1-sided exact probability test, $\mathrm{p}=0 \cdot 15$ ).

\section{HAEMATOLOGICAL VARIABLES}

Comparison of haematological variables in patients with and without PSR showed significant associations of PSR with high $\mathrm{Hb}$ in SS males and a low $\mathrm{HbF}$ in SS patients of both sexes (Table VI). In SC disease there were associations with high $\mathrm{Hb}$ and high $\mathrm{MCHC}$ in males and with high MCV and low HbF in both sexes (Table VII).

Further examination of these relationships by multiple logistic regression analysis, which allows for effects of age and for interrelationships between haematological variables, showed that in SS disease both the high $\mathrm{Hb}$ for males and low $\mathrm{HbF}$ in both sexes remained significant (Table VIII). In SC disease all the significant relationships in males apparent on simple regression were no longer significant, though a low $\mathrm{HbF}$ and a high MCV remained significant in females. The effects of these factors can be illustrated by using the fitted logistic regression models to predict the probability of PSR. For example, a 35-year-old SS male with $\mathrm{Hb} 7 \mathrm{~g} / \mathrm{dl}$ and $\mathrm{HbF} 6 \%$ would have a $6 \%$ chance of having PSR, whereas with $\mathrm{Hb} 10 \mathrm{~g} / \mathrm{dl}$ and $\mathrm{HbF} 1 \cdot 5 \%$ this would rise to 53\%. A 35-year-old SC female with $\mathrm{Hb} 12 \mathrm{~g} / \mathrm{dl}$, mean corpuscular haemoglobin concentration (MCHC) $35 \mathrm{~g} / \mathrm{dl}$, mean cell volume (MCV) $75 \mathrm{fl}$, and $\mathrm{HbF} 2 \%$ would have a $29 \%$ chance of having PSR, though changing the latter two indices to $90 \mathrm{fl}$ and $0.5 \%$ would increase this chance to $92 \%$.

The $\alpha$ globin gene number was known in 351/ 786 (45\%) SS patients. PSR was observed at the first visit in 2/42 (5\%) SS patients homozygous for $\alpha$ thalassaemia, $8 / 116$ (7\%) SS patients heterozygous for $\alpha$ thalassaemia, and 15/192 (8\%) SS patients with a normal $\alpha$ globin gene complement, with no significant difference between groups. Among SS patients with a normal $\alpha$ globin gene complement PSR occurred in $10 / 82(12 \%)$ males compared with $5 / 110(5 \%)$ females, though this difference just failed to reach statistical significance $(z=1.95, p=0.051)$. No $\alpha$ globin gene number data were available in $\mathrm{SC}$ disease.

\section{Discussion}

The observation that proliferative sickle retinopathy occurs at such high frequency in a generally benign genotype of sickle cell disease is of considerable interest. Most patients with sickle cell haemoglobin $\mathrm{C}$ disease run a mild clinical

TABLE VI Some haematological indices in 740 patients with SS disease with and without proliferative sickle retinopathy

\begin{tabular}{|c|c|c|c|c|c|c|c|c|c|c|}
\hline & \multicolumn{5}{|l|}{ Males } & \multicolumn{5}{|l|}{ Females } \\
\hline & \multicolumn{2}{|c|}{$P S R+v e(n=41)$} & \multicolumn{2}{|c|}{$P S R-v e(n=265)$} & \multirow{2}{*}{$\begin{array}{l}\text { Significance } \\
t\end{array}$} & \multicolumn{2}{|c|}{$P S R+v e(n=46)$} & \multicolumn{2}{|c|}{$P S R-v e(n=388)$} & \multirow{2}{*}{${ }_{t}^{\text {Significance }}$} \\
\hline & Mean & $S D$ & Mean & $S D$ & & Mean & $S D$ & Mean & $S D$ & \\
\hline $\begin{array}{l}\mathrm{Hb}(\mathrm{g} / \mathrm{dl}) \\
\text { MCHC }(\mathrm{g} / \mathrm{dl}) \\
\text { MCV }(\mathrm{f}) \\
\text { Reticulocytes }(\%) \\
\log _{10}(\mathrm{HbF}+\mathrm{l}) \dagger \\
\text { Platelets }\left(\times 10^{9} / \mathrm{l}\right) \\
\log _{10} \text { bilirubin } \dagger \\
\text { Serum iron }(\mathrm{mmol} / \mathrm{l})\end{array}$ & $\begin{array}{c}8 \cdot 81 \\
33 \cdot 8 \\
86 \cdot 7 \\
9 \cdot 5 \\
0 \cdot 58(2 \cdot 8) \\
372 \\
1 \cdot 70(50) \\
16 \cdot 8\end{array}$ & $\begin{array}{c}1.59 \\
1.5 \\
8.0 \\
3.4 \\
0.22 \\
122 \\
0.21 \\
4.9\end{array}$ & $\begin{array}{l}8.06 \\
33.9 \\
87 \cdot 4 \\
10.5 \\
0.69(3.9) \\
417 \\
1.68(48) \\
15.9\end{array}$ & $\begin{array}{c}1 \cdot 20 \\
1 \cdot 7 \\
7 \cdot 9 \\
3 \cdot 6 \\
0 \cdot 25 \\
142 \\
0 \cdot 23 \\
4 \cdot 7\end{array}$ & $\begin{array}{l}3.65^{\star \star \star} \\
0.43 \\
0.50 \\
1.71 \\
2.63^{\star \star} \\
1.88 \\
0.68 \\
1.55\end{array}$ & $\begin{array}{l}7 \cdot 75 \\
33 \cdot 5 \\
89 \cdot 2 \\
10 \cdot 5 \\
0 \cdot 71(4 \cdot 1) \\
419 \\
1.63(43) \\
15 \cdot 0\end{array}$ & $\begin{array}{c}1 \cdot 16 \\
1 \cdot 6 \\
8 \cdot 7 \\
3 \cdot 5 \\
0 \cdot 23 \\
130 \\
0 \cdot 22 \\
4 \cdot 3\end{array}$ & $\begin{array}{c}7 \cdot 88 \\
33 \cdot 9 \\
89 \cdot 3 \\
10 \cdot 1 \\
0 \cdot 80(5 \cdot 3) \\
423 \\
1 \cdot 65(45) \\
16 \cdot 3\end{array}$ & $\begin{array}{c}1 \cdot 05 \\
1 \cdot 7 \\
7 \cdot 9 \\
3 \cdot 3 \\
0 \cdot 24 \\
138 \\
0.21 \\
5 \cdot 5\end{array}$ & $\begin{array}{l}0 \cdot 76 \\
1.49 \\
0 \cdot 08 \\
0 \cdot 73 \\
2 \cdot 71^{\star \star} \\
0 \cdot 16 \\
0.68 \\
1.50\end{array}$ \\
\hline
\end{tabular}

†Figures in parentheses are means re-expressed in original units, $\mathrm{HbF}(\%)$, bilirubin $(\mathrm{mmol} / \mathrm{l})$. Significance: ${ }^{\star} \mathrm{p}<0.05 ;{ }^{\star \star} \mathrm{p}<0.01 ;{ }^{\star \star \star} \mathrm{p}<0 \cdot 001$.

TABLE VII Some haematological indices in 441 patients with SC disease with and without proliferative sickle retinopathy

\begin{tabular}{|c|c|c|c|c|c|c|c|c|c|c|}
\hline & \multicolumn{5}{|l|}{ Males } & \multicolumn{5}{|l|}{ Females } \\
\hline & \multicolumn{2}{|c|}{$P S R+v e(n=105)$} & \multicolumn{2}{|c|}{$P S R-v e(n=97)$} & \multirow{2}{*}{$\begin{array}{l}\text { Significance } \\
t\end{array}$} & \multicolumn{2}{|c|}{$P S R+v e(n=97)$} & \multicolumn{2}{|c|}{$P S R-v e(n=142)$} & \multirow{2}{*}{${ }_{t}$ Significance } \\
\hline & Mean & $S D$ & Mean & $S D$ & & Mean & $S D$ & Mean & $S D$ & \\
\hline $\begin{array}{l}\mathrm{Hb}(\mathrm{g} / \mathrm{dl}) \\
\text { MCHC }(\mathrm{g} / \mathrm{dl}) \\
\text { MCV }(\mathrm{fl}) \\
\text { Reticulocytes }(\%) \\
\text { Log }_{10}(\mathrm{HbF}+1) \dagger \\
\text { Platelets }\left(\times 10^{\circ} / \mathrm{l}\right) \\
\text { Log }_{10} \text { bilirubin } \dagger \\
\text { Serum iron }(\mathrm{mmol} / \mathrm{l})\end{array}$ & $\begin{array}{c}12 \cdot 82 \\
35 \cdot 9 \\
84 \cdot 9 \\
4 \cdot 0 \\
0 \cdot 26(0 \cdot 8) \\
265 \\
1 \cdot 40(25) \\
15 \cdot 3\end{array}$ & $\begin{array}{c}1 \cdot 36 \\
1 \cdot 2 \\
6 \cdot 2 \\
1 \cdot 4 \\
0 \cdot 15 \\
114 \\
0 \cdot 20 \\
5 \cdot 1\end{array}$ & $\begin{array}{c}12 \cdot 14 \\
35 \cdot 5 \\
80 \cdot 6 \\
3 \cdot 9 \\
0 \cdot 32(1 \cdot 1) \\
287 \\
1 \cdot 38(24) \\
15 \cdot 5\end{array}$ & $\begin{array}{c}1.35 \\
1.4 \\
7 \cdot 0 \\
1.5 \\
0 \cdot 21 \\
108 \\
0.20 \\
4.5\end{array}$ & $\begin{array}{l}3 \cdot 52^{\star \star \star} \\
2 \cdot 31^{\star} \\
4 \cdot 64^{\star \star \star} \\
0 \cdot 59 \\
2 \cdot 42^{\star} \\
1 \cdot 32 \\
0 \cdot 51 \\
0 \cdot 41\end{array}$ & $\begin{array}{l}11 \cdot 23 \\
35 \cdot 5 \\
83 \cdot 3 \\
3 \cdot 8 \\
0 \cdot 28(0 \cdot 9) \\
263 \\
1 \cdot 31(20) \\
14 \cdot 4\end{array}$ & $\begin{array}{c}1 \cdot 17 \\
1.2 \\
6 \cdot 0 \\
1 \cdot 3 \\
0 \cdot 15 \\
106 \\
0 \cdot 16 \\
4 \cdot 5\end{array}$ & $\begin{array}{c}11 \cdot 30 \\
35 \cdot 7 \\
80 \cdot 4 \\
4 \cdot 0 \\
0 \cdot 36(1 \cdot 3) \\
264 \\
1 \cdot 31(20) \\
14 \cdot 0\end{array}$ & $\begin{array}{l}1 \cdot 03 \\
1 \cdot 4 \\
6 \cdot 6 \\
1 \cdot 7 \\
0 \cdot 20 \\
99 \\
0 \cdot 22 \\
4 \cdot 4\end{array}$ & $\begin{array}{l}0 \cdot 50 \\
0 \cdot 87 \\
3 \cdot 42^{\star \star \star} \\
0 \cdot 74 \\
3 \cdot 13^{\star \star \star} \\
0 \cdot 10 \\
0 \cdot 26 \\
0.70\end{array}$ \\
\hline
\end{tabular}

†Figures in parentheses are means in original units, $\mathrm{HbF}(\%)$, bilirubin $(\mathrm{mmol} / \mathrm{l})$. Significance: ${ }^{\star} \mathrm{p}<0.05 ;{ }^{\star \star} \mathrm{p}<0 \cdot 01 ;{ }^{\star \star \star} \mathrm{p}<0.001$ 
TABLE VIII Relationship of selected haematological indices and proliferative sickle retinopathy analysed by multiple logistic regression

\begin{tabular}{|c|c|c|c|c|c|c|c|c|}
\hline & \multicolumn{4}{|l|}{$S S$} & \multicolumn{4}{|l|}{$S C$} \\
\hline & \multicolumn{2}{|l|}{ Males } & \multicolumn{2}{|c|}{ Females } & \multicolumn{2}{|l|}{ Males } & \multicolumn{2}{|c|}{ Females } \\
\hline & Slope & $p$ & Slope & $p$ & Slope & $p$ & Slope & $p$ \\
\hline $\begin{array}{l}\mathrm{Hb} \\
\log _{10}(\mathrm{HbF}+1) \\
\text { MCV } \\
\text { MCHC }\end{array}$ & $\begin{array}{r}0.56 \\
-2.55\end{array}$ & $\begin{array}{r}<0.001 \\
0.003\end{array}$ & $\begin{array}{r}0.26 \\
-2.53\end{array}$ & $\begin{array}{c}0.1 \\
<0.001\end{array}$ & $\begin{array}{r}-0.01 \\
-1.12 \\
0.05 \\
0.21\end{array}$ & $\begin{array}{l}0.99 \\
0 \cdot 3 \\
0 \cdot 08 \\
0 \cdot 2\end{array}$ & $\begin{array}{c}-0 \cdot 10 \\
-4 \cdot 5 \\
0 \cdot 13 \\
-0 \cdot 30\end{array}$ & $\begin{array}{c}0.6 \\
<0.001 \\
<0.001 \\
0.07\end{array}$ \\
\hline
\end{tabular}

course with near normal haematology and infrequent vaso-occlusive episodes. Patients with homozygous sickle cell disease generally have frequent vaso-occlusion and a severe clinical course, yet proliferative sickle retinopathy is significantly less frequent. This enigma suggests that the two genotypes may be useful models for understanding the risk factors for PSR.

One hypothesis attempting to reconcile this unexpected observation envisaged three models with different vaso-occlusive tendencies. ${ }^{11}$ Patients with low vaso-occlusive indices would be unlikely to develop retinal ischaemia and therefore have no stimulus to develop PSR. Patients with moderate vaso-occlusive indices would develop peripheral retinal closure and proceed to the development of preproliferative or proliferative disease. Patients with high vasoocclusive indices would develop extensive peripheral retinal vascular closure, with a stimulus to PSR formation, but would proceed to occlude preproliferative arteriovenous anastomoses or nascent PSR. It was proposed that SC disease represented the intermediate model, with sufficient vaso-occlusion to produce retinal ischaemia but insufficient to occlude the lesions of developing PSR. An analogous situation would be the persistence of splenomegaly in SS patients with high levels of $\mathrm{HbF},{ }^{12}$ representing the survival of a capillary bed not damaged by vaso-occlusion and hence an expression of pathological mildness.

This hypothesis implies that the risk factors for retinal vaso-occlusion may differ from those for PSR. Only limited data are available on the risk factors for peripheral retinal vaso-occlusion. Observations in the Jamaican cohort study confirmed that closure generally increased progressively with age, was more common in males than females at an early age, and was not significantly more frequent in SS disease. ${ }^{13}$ Analysis of haematological risk factors in SS disease showed that retinal closure was significantly associated with low total haemoglobin, low fetal haemoglobin, a high reticulocyte count, and high counts of irreversibly sickled cells. ${ }^{14}$ The effect of total haemoglobin disappeared on multiple logistic regression, ${ }^{14}$ suggesting that its effect was entirely secondary to its relationship with $\mathrm{HbF}$, but a later matched pairs analysis of patients with minimal or complete closure ${ }^{13}$ showed an independent effect of haemoglobin level. In SS disease, therefore, closure was associated with low $\mathrm{Hb}$, low $\mathrm{HbF}$, high reticulocyte, and high ISC counts whereas PSR was associated with a high $\mathrm{Hb}$ (males only) and low HbF. In SC disease closure was associated with a high reticulocyte count, ${ }^{14}$ though this was not apparent on a later matched pairs analysis, which showed effects of high MCV and low platelet counts. ${ }^{13}$ By contrast haematological risk factors for PSR in SC disease were apparent only in females and included a high MCV and low HbF.

The results of analysis for haematological risk factors for PSR in the present study are broadly similar to previous observations. In SS disease observations in males were identical to those of Hayes et $a l,{ }^{1}$ whereas in females a previously noted and unexplained contribution of low serum iron was lost, and an effect of low $\mathrm{HbF}$ has emerged in the present study. In SC disease the results on simple regression in males were again identical to those of an earlier study, ${ }^{2}$ though logistic regression in the currently available larger data set shows that none of the apparent contributions of high $\mathrm{Hb}$, low $\mathrm{HbF}$, high $M C H C$, and high MCV remain significant. In females only a low $\mathrm{HbF}$ was significant in the earlier study, but a high MCV also appears to be a risk factor.

These haematological data may contribute to the understanding of the mechanisms of PSR formation, since different indices are believed to affect flow in different sized vessels. Thus flow in large vessels is affected predominantly by viscosity (haemoglobin, haematocrit) or number of particles (red cell count), whereas flow in the capillary bed is affected by the characteristics of the individual red cells such as membrane deformability and intracellular viscosity. In sickle cell disease the latter is particularly affected not only by the MCHC but also by $\mathrm{HbF}$, which affects the intracellular polymerisation of $\mathrm{HbS}$. The haematological data are therefore more consistent with a capillary site of obstruction. Furthermore the lack of demonstrable differences in blood viscosity between groups with and without PSR in SS ${ }^{11}$ and SC $^{10}$ disease is less consistent with a role of larger vessel flow. The elegant angiographic studies of Galinos et $a l^{15}$ showing non-perfusion at or near $\mathrm{Y}$ shaped branches of the precapillary arterioles would be consistent with either interpretation.

Other observations in the present study have contributed to the understanding of PSR. Both the prevalence and incidence data show that PSR is rare in the first decade, suggesting that extensive retinal damage must have accumulated before the PSR develops. The high frequency of bilaterality suggest that systemic factors contribute to the development of PSR, though the lack of simultaneous development argues against a role of acute haematological change or a severe clinical event. The analysis of familial clustering was limited by the relatively small numbers available, and, though showing a trend in that there was a slight excess of families in which all or none of the siblings had PSR, the differences were far short of significance, contrary to our clinical impression.

Do the available data fit the hypothesis? The first model of low vaso-occlusive indices is selfevident, since PSR does not develop in the absence of retinal ischaemia. However, this is likely to be a small group, since retinal closure occurred in approximately $90 \%$ children by 12 years of age,,$^{13}$ the factors protecting against closure being either homozygous $\alpha$ thalassaemia or very high levels of $\mathrm{HbF}$. The middle group 
with moderate vaso-occlusive indices should include the majority of SC patients and a smaller proportion of those with SS disease. The group with high vaso-occlusive indices should contain predominantly patients with SS disease. This genotype is already recognised to be associated with increased autoinfarction of established PSR, ${ }^{16}$ but, if the hypothesis is correct, patients with the greatest vaso-occlusion should be experiencing preproliferative changes and not proceeding to the development of PSR.

Testing the hypothesis requires an accurate indicator of vaso-occlusive tendency. Using $\mathrm{HbF}$ level as such an indicator, we could not demonstrate a lower frequency of PSR among those with the lowest $\mathrm{HbF}$ levels. Although inconsistent with the hypothesis, this observation casts doubt on the validity of $\mathrm{HbF}$ as an indicator of vaso-occlusion and does not necessarily refute the hypothesis.

We thank other ophthalmologists associated with the Jamaican ophthalmic studies, especially Mr Patrick Condon, Rober Acheson, and Brendan Moriarty, who have all contributed to the data. We thank Dr Douglas Higgs for the studies on $\alpha$ globin gene number.

1 Hayes RJ, Condon PI, Serjeant GR. Haematological factors associated with proliferative retinopathy in homozygous sickle cell disease. Br 7 Ophthalmol 1981; 65: 29-35.

2 Hayes RJ, Condon PI, Serjeant GR. Haematological factors associated with proliferative retinopathy in sickle cellhaemoglobin C disease. Brf Ophthalmol 1981; 65: 712-7.

3 Serjeant BE, Forbes M, Williams LL, Serjeant GR. Screening cord bloods for detection of sickle cell disease in Jamaica. Clin Chem 1974; 20: 666-9.

4 Serieant GR. Sickle cell disease. Oxford: Oxford University Press, 1985: 37-40.

5 Betke K, Marti HR, Schlicht I. Estimation of small percentages of foetal haemoglobin. Nature 1959; 184: 1877-8.

6 Lathe GM, Ruthven CRJ. Factors affecting the rate of coupling of bilirubin and conjugated bilirubin in the van den Bergh reaction. F Clin Pathol 1958; 11: 155-61.

7 Beale RN, Bostrum JO, Taylor RF. Improved rapid method for the determination of iron content and binding capacity of serum. F Clin Pathol 1962; 15: 156-60.

8 Higgs DR, Pressley L, Serjeant GR, Clegg JB, Weatherall DJ. The genetics and molecular basis of alpha thalassaemia in association with $\mathrm{HbS}$ in Jamaican Negroes. $\mathrm{Br} \mathcal{F}$ Haematol 1981; 47: 43-56.

9 Nelder JA, Wedderburn RWM. Generalised linear models. F R Statist Soc $(A)$ 1972; 135: 370-84

10 Serjeant BE, Mason KP, Condon PI, et al. Blood rheology and prolifeative sickle retinopathy in sickle cell-haemoglobin $C$ disease. Br F Ophthalmol 1984; 68: 325-8.

11 Serjeant BE, Mason KP, Acheson RW, Maude GH, Stuart J, Serjeant GR. Blood rheology and proliferative sickle retinopathy in homozygous sickle cell disease. $\mathrm{Br} \mathcal{F}$ Ophthalmol 1986; 70: 522-5.

12 Serjeant GR. Irreversible sickle cells and splenomegaly in sickle-cell anaemia. $B r \mathcal{F}$ Haematol 1970; 19: 635-41.

13 Talbot JF, Bird AC, Maude GH, Acheson RW, Moriarty BJ, Serjeant GR. Sickle cell retinopathy in Jamaican children: further observations from a cohort study. Br $\mathcal{J}$ Ophthalmol further observations

14 Talbot JF, Bird AC, Rabb LM, Maude GH, Serjeant GR. Sickle cell retinopathy in Jamaican children: a search for prognostic factors. Brf Ophthalmol 1983; 67: 782-5.

15 Galinos SO, Asdourian GK, Woolf MB, et al. Spontaneous remodeling of the peripheral retinal vasculature in sickling disorders. Am f Ophthalmol 1975; 79: 853-70.

16 Condon PI, Serjeant GR. Behaviour of untreated proliferative sickle retinopathy. Br 7 Ophthalmol 1980; 64: 404-11. 